\title{
DA SENZALA AO CÁRCERE: CORPO E MATERNIDADE ÀS MARGENS DA HISTÓRIA
}

\section{FROM SENZALA TO PRISION: BODY AND MATERNITY TO THE MARGINS OF HISTORY}

\author{
Aline Fernandes de Azevedo Bocchi \\ Universidade de Franca, UNIFRAN, Franca, SP, Brasil
}

\begin{abstract}
Resumo: Neste artigo, objetivamos a compreensão dos efeitos sentidos para o corpo e a maternidade da mulher negra, a partir de um trajeto de leitura situado no encontro entre memória e acontecimento, o qual permite vislumbrar a radicalidade da experiência do olhar. Para tanto, discutimos o estatuto desigual da condição de existência da mulher negra em gestos de análise discursiva da pintura, particularmente, da tela Mãe preta, e de duas fotografias, de babás e crianças, representativas do Brasil oitocentista, articulando-as a uma postagem na rede social Facebook em que a maternidade nas prisóes e penitenciárias brasileiras é tematizada.
\end{abstract}

Palavras-chave: corpo; maternidade; olhar; imagem; enquadramento.

Abstract: The aim of this article is to understand the meanings of the body and motherhood of black women, based on readings concerning the encounter between memory and event, which enables us to observe the radicality of the experience of looking. To do this, the unequal status of a black woman's existence in gestures of discursive analysis of paintings is discussed, particularly the Mãe preta (Black Mother) canvas, and two photographs of nannies and children showing nineteenth-century Brazil, articulating them to a post in the Facebook social network where maternity in Brazilian prisons and penitentiaries is thematized.

Keywords: body; maternity; looking; image; framework.

\section{Introdução}

Por onde passam os sentidos de maternidade no que diz respeito à mulher negra? Essa questáo norteia a reflexáo proposta para este texto, cujo objetivo é problematizar o caráter profundamente dividido dos discursos sobre a maternidade no Brasil. Tomando como objeto de reflexão a relação entre indivíduo e sociedade, consideramos que o modo como o Estado individua o sujeito determina a natureza de sua relação com a sociedade (ORLANDI, 
2009), o que implica dizer que a compreensão de uma maternidade possível para a mulher negra passa por sua relação com o Estado a instituir processos de segregação que interditam sua necessidade, enquanto sujeito sócio histórico e simbólico, de praticar laços sociais. Tendo em vista essas reflexóes, no exame de modos de constituição, formulação e circulação de sentidos (ORLANDI, 2001), buscamos compreender o modo pelo qual a pintura, a fotografia e o post, enquanto distintas materialidades significantes, produzem sentidos para a maternidade, privilegiando versóes subalternas. Nessa trilha, investigamos vestígios que indiquem processos de assujeitamento à ideologia a constituírem sentidos para os corpos das mulheres negras e, paradoxalmente, lugares para a fuga de sentidos (ORLANDI, 2012b) ideologicamente sedimentados, a constituírem efeitos de resistência, em um trajeto que historiciza os materiais para os quais lanço um olhar e uma escuta, num exercício de "escuta social" análogo à "escuta analítica" da prática freudiana, conforme proposto por Pêcheux (HENRY, [1969] 2010, p. 52-53).

Analisamos, então, quatro fragmentos que compóem, no gesto de leitura ensaiado, enquadramentos de sentido sobre a maternidade e o corpo negro feminino em diferentes momentos históricos, com suas marcas de historicidade e suas relaçóes de contradição, subordinação e desigualdade. São eles: a) a tela Mãe preta, pintada em 1912 por Lucílio de Albuquerque e que hoje integra o acervo do Museu de Belas Artes da Bahia, em Salvador; b) a fotografia Babá brincando com criança em Petrópolis, clicada em 1899 por Jorge Henrique Papf; c) a interferência sobre a fotografia Babá com menino Eugen Keller para a mostra Mãe Preta, organizada por Isabel Löfgren e Patricia Gouvêa (2018); d) por fim, uma postagem "comemorativa" ao dia das mães na rede social Facebook, em que a maternidade nas prisóes e penitenciárias brasileiras é tematizada, publicada pela organização não-governamental Artemis. O eixo organizador dos recortes é a noção de memória entrecruzada com a de acontecimento, tal como são definidas pela Análise de Discurso de orientação materialista (BALDINI; ZOPPI-FONTANA, 2014).

Esses recortes solicitam corpos como significantes em tensão e dizem de espaços divididos, assinalando as fronteiras entre as formaçóes discursivas; enquadramentos e demarcaçóes sobre o corpo e a vida que dizem respeito à condição de existência da mulher negra; e imagens da violência, que inquietam e capturam o olhar do leitor, interpelando-o e exigindo dele uma escuta. Trata-se, portanto, de um corpus construído a partir de flagrantes de corpos em conflito, em que é possível problematizar a radicalidade da experiência do olhar, tendo em vista que a leitura da imagem, sua escuta social, convoca também o corpo do analista, o qual deve deslocar-se do lugar 
de puro observador para realizar seus gestos de análise, na relação com os procedimentos teórico-metodológicos. A composição do corpus guarda, assim, uma "tensa relação entre o dentro e o fora, entre o corpo do sujeito e o corpo social" (ORLANDI, 2010, p. 634), em que se coloca fortemente a questão da alteridade, na relaçáo entre a ordem do repetível e daquilo que nela faz furo.

A partir dessa articulação conceitual, a análise discorrerá sobre uma distribuição desigual do estatuto de pessoa, na qual jogam o reconhecimento e o enquadramento: ao questionar quais enquadramentos permitem a representabilidade do humano, Judith Butler (2015, p. 22) articula o campo do reconhecível e do apreensível: "não há vida nem morte sem relação com um determinado enquadramento", afirma. Em sua elaboração, ela coloca em jogo o campo visual, no qual to be framed implica tanto a ideia de enquadramento como delimitaçáo própria ao campo da imagem, quanto a ideia de moldura. Temos, então, na sequência de recortes construída para esta análise, enquadramentos de maternidade atravessados por divisóes, barreiras que cortam as sociedades como linhas móveis a demarcar margens entre as formaçôes discursivas sulcando fronteiras (in)visíveis no dizer, ou melhor, nas formulaçóes visuais ora analisadas.

\section{Posiçóes teóricas: materialidades discursivas, acontecimento, memó- ria}

Em abril de 1980, Pêcheux (2016) abre o Colóquio Matérialités Discursives com uma provocação concernente a uma tripla asserção, referente ao real da língua, ao real do inconsciente e ao real da história, a qual manifesta uma relação problemática originária precisamente do que entre língua, história e inconsciente resulta como heterogeneidade irredutível. Perguntando-se sobre quais materialidades se colocam em jogo na análise dos discursos nos domínios da História, da Psicanálise e da Linguística, ele inaugura uma discussão capaz de livrar o analista de discurso de uma ortopedia de leitura restrita à contemplação da reprodução do sentido, engajando a prática de análise discursiva na compreensão da produção de acontecimentos. Ao perscrutar o que há de perturbador e inquietante na compreensão do funcionamento de um acontecimento discursivo, que vem abalar a religiáo do sentido, Pêcheux coloca à prova o "fantasma teórico unificador" e, com ele, a possibilidade de conciliação irrestrita das heterogeneidades provenientes dessas disciplinas. 
$\mathrm{O}$ autor caracteriza sua posição de trabalho a partir da via que entrecruza três caminhos: "o do acontecimento, o da estrutura e o da tensão entre descrição e interpretaçáo" (PÊCHEUX, 2002, p. 19) no interior da Análise de Discurso. O acontecimento, definido como ponto de encontro de uma atualidade e uma memória, torna-se não só fundamental nas reflexôes acerca da materialidade do discurso, mas também a consideração daquilo que escapa a toda simbolização, posto que "o real da língua não é costurado nas suas margens como uma língua lógica: ele é cortado por falhas" (GADET; PÊCHEUX, 2010, p. 55). Em consequência, os efeitos na/da linguagem permitem abarcar a equivocidade em lapsos, atos falhos, chistes e sintomas em relação aos processos de constituição do sujeito e dos sentidos.

Além de colocar em cena a contingência da história e seus efeitos sobre as estruturas, a noçáo de acontecimento exige uma reformulaçáo na própria noção de língua, que passa a ser definida por/em suas falhas, na incompletude. Ao situar a Análise de Discurso no espaço incerto, onde língua e história se encontram submetidas à interpretaçáo, a questão teórica colocada por Pêcheux (2002, p. 28) articula-se ao estatuto das discursividades que trabalham um acontecimento, discursividades que entrecruzam posiçóes logicamente estabilizadas e unívocas a formulações equívocas. Assim, a posição de trabalho sustentada por Pêcheux (2002, p. 43) nos deixa em face de um real "constitutivamente estranho à univocidade lógica” e a um saber que não se reduz à ordem das "coisas-a-saber". Um real que náo se descobre: "a gente se depara com ele, dá de encontro com ele, o encontra” (PÊCHEUX, 2002, p. 29).

A memória, para Pêcheux (2007, p. 56), é um espaço móvel de divisóes, marcado por conflitos entre retomadas e deslocamentos: "um espaço de desdobramentos, réplicas, polêmicas e contra-discursos”. Não homogênea, a memória, para a Análise de Discurso, comporta falhas e buracos, admite a exterioridade como marca do real histórico. Ela não diz respeito, portanto, ao que entendemos como memória individual ou lembrança de um sujeito particular, mas aos "sentidos entrecruzados da memória mítica, da memória social inscrita em práticas, e da memória construída do historiador" (PÊCHEUX, 2007, p. 50). Trata-se, assim, de um funcionamento que acolhe o movimento entre repetiçáo e deslocamento, definido como tensão contraditória constitutiva do processo de inscrição do acontecimento no espaço da memória. $\mathrm{O}$ acontecimento é definido, então, como aquilo que vem perturbar a memória, provocando interrupçóes que podem vir a desmanchar processos de regularização. 
A partir dessa posição teórica, interrogamos quais relaçóes as diferentes materialidades discursivas em questão neste trabalho - não só a pintura e a fotografia, mas também o post em uma rede social digital -, suas especificidades em termos de formulação, constituição e circulação, estabelecem, com a memória e com o acontecimento, sentidos para a maternidade. Tendo em vista a condição material de existência, consideramos que os sentidos possíveis para a maternidade da mulher negra surgem como restos impronunciáveis da história e, para sustentar essa posição, traçamos uma compreensão da ideologia que não apaga sua relação inequívoca com o registro inconsciente. Essa posição articula-se à especificidade da análise materialista de discurso em face de outras perspectivas de tratamento das discursividades. Colocá-las, desde já, como ponto nodal da reflexão ora proposta é conferir ao trabalho teórico um lugar fundamental "contra o fogo incinerador que só produz fumaça" (PÊCHEUX, 2009, p. 294), tomando partido pelo fogo de um trabalho crítico.

\section{Máe preta e a radicalidade da experiência do olhar}

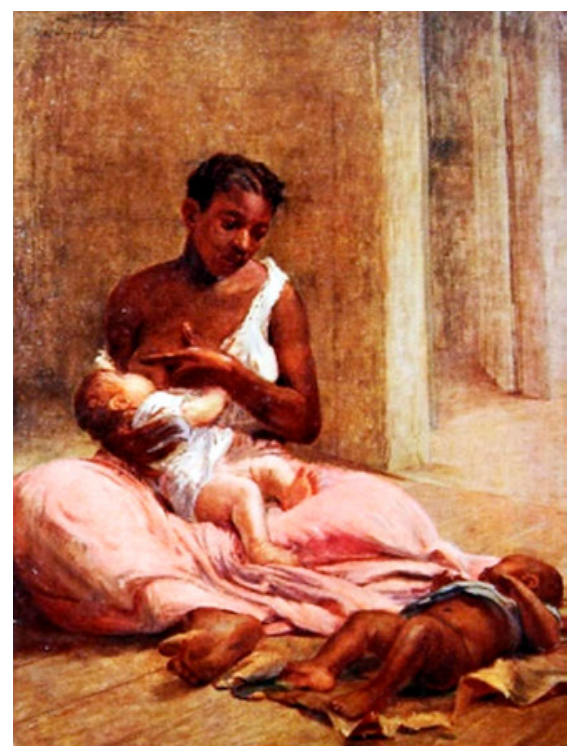

Figura 1: Tela Mãe preta, de Lucílio de Albuquerque (1912), acervo do Museu de Belas Artes de Salvador.

Fonte: MÃE Preta, 2019. 
Mãe preta, mãe de leite, ama-de-leite: substantivo feminino, "mulher que amamenta criança alheia”, segundo o Dicionário Priberam da Língua Portuguesa. Na tela Mãe preta (Figura 1), pintada em 1912 por Lucílio de Albuquerque, a crueza da violência com que a mulher mãe negra é formulada apreende o olhar do leitor, assombrado pela força perturbadora que irrompe na pintura, no olhar de uma mãe em direçáo ao seu filho, esse ponto de captura o qual Barthes (2015) nomeou punctun ${ }^{1}$ : espécie de picada, buraco, ferida sócio-histórica que punge na tela, pois retira da imagem sua suposta transparência; ponto de fuga que desestabiliza a evidência na constituição de sentidos para a mulher negra. Sentado no chão, em um cenário assombrado pelo vazio, jaz um corpo de mulher a nutrir um bebê, corpo negro que, ao amamentar a criança branca, vislumbra um outro. Ressonância da falta na constituiçáo do sujeito, o olhar, enquanto ponto de captura, é também o vestígio a partir do qual a obra se abre em equívocos, numa poética que diz do não-todo, indicativa da tensão instaurada pela divisão do sujeito. Em seu semblante de resignação muda, apreendido por entre as pinceladas que enquadram uma cena de intimidade, o corpo feminino negro urdido na tela permite ponderar a radicalidade da experiência do olhar. Máe preta, talvez, possa nos dar um vislumbre da imagem que nos olha, posto que, para simbolizar a maternidade da mulher negra na formação social escravista, instala uma relaçáo indiscreta entre beleza e perversidade.

Interpretada pelos portugueses como instintiva e primitiva, não digna da mulher civilizada, a amamentaçáo fora delegada, no período colonial brasileiro, às índias tupinambás devido à sua cultura de amamentar seus filhos até dois anos ou mais. Foram as jovens índias as primeiras amasde-leite da história deste país, função que rapidamente passou às escravas negras, surgindo, segundo Gilberto Freyre (1978), uma nova figura social importante no Brasil escravista: a mãe preta de aluguel. Propriedade e mercadoria escrava leiteira, eram mulheres obrigadas a cuidar e nutrir o filho branco do senhor, à custa do afastamento e abandono de seus próprios filhos, que muitas vezes eram vendidos com poucos meses de vida, como evidencia a formulação que figura no anúncio publicado no Jornal do Commercio de 03 de agosto de 1850: "Aluga-se uma preta para ama com muito bom leite, de 40 dias e de primeiro parto, é muito carinhosa para as crianças, não tem

\footnotetext{
${ }^{1}$ Embora Barthes tenha discorrido sobre o punctun em relação ao "signo fotográfico", definindo-o como o acaso que fere seu espectador, o apunhala e mortifica, consideramos o termo bastante apropriado como entrada para esta análise, pois possibilita estabelecer uma relação entre a imagem e seu espectador pela via do sensível, permitindo-nos traçar uma compreensão sobre aquilo que, na imagem, resta como indizível.
} 
vício algum e é muito sadia; e também se vende a cria" (MAGALHÃES; GIACOMINI, 1983, p. 77).

No modo como constitui sentidos, para a mulher mãe negra e seu filho recém nascido, o anúncio materializa, no discurso, práticas perversas e naturalizadas para significarem a amamentação e o cuidado da mulher negra, ancorado no discurso escravista e na sua definição premente das "mães escravas" como reprodutoras da mão de obra cativa, constitutiva do conceito legal de partus sequitur ventrem (o parto segue o ventre) amplamente defendido por proprietários de escravos e juristas como solução ao problema da reprodução da mão de obra escrava após a cessação legal do tráfico de africanos em $1831^{2}$. Carregados de violência de gênero e raça, artificiosos e ardilosos por não aparecerem necessariamente sob a forma do chicote, os discursos que significam a mãe preta no Brasil oitocentista se esforçam por naturalizar uma condição de animalização e mansidão, como observado em anúncios da época ${ }^{3}$ em que essas mulheres eram descritas como animais domesticados, próprios a realizar tarefas não só como nutrizes e cuidadoras, mas tantas outras relativas aos serviços domésticos.

Pintado pouco depois da assinatura da Lei Áurea, o drama urdido em Máe preta se organiza a partir da ordem do repetível, posto que atualiza sentidos estabilizados na formaçáo social profundamente dividida do período da recente abolição, configurando, assim, uma "cena prototípica", na definiçáo elaborada por Lagazzi (2015, p. 177). Trata-se, segundo a autora, de cenas que dão a ver um social dividido, isto é, tipificam a divisão social intrincada em relaçôes dicotômicas e disjuntivas, nas quais trabalham a alteridade e a diferença. Embora pensada em relação à formulação audiovisual, que intrinca imagem e som em movimento, a noção de "cena prototípica" é relevante para este trabalho, pois permite compreender a resistência a partir da divisão; na cena em análise, apesar de haver uma espécie de sintetização do já-dito, o olhar materializa vestígios de uma resistência possível para essa mulher que, ao vislumbrar um outro, rejeita uma posição sujeito. A noção de cena prototípica permite, então,

${ }^{2}$ É importante lembrar que a Lei do Ventre Livre foi promulgada apenas em 1871, quarenta anos depois da proibiçấo do tráfico de africanos escravizados.

${ }^{3}$ Exemplares de anúncios de venda e aluguel de amas de leite podem ser encontrados, entre outros lugares, no catálogo da exposição Mãe Preta, com curadoria e pesquisa de Isabel Löfgren e Patricia Gouvêa (2018), realizada no Rio de Janeiro, São Paulo e Sáo Luiz do Maranháo em 2018 e início de 2019. Nesse tenso e sedicioso arquivo, observamos características atribuídas às amas, textualizadas em formulaçóes dispostas entre anúncios de vendas de imóveis e mobília: "ama com bom leite", "engomma muito bem", "mui sadia", "sem molestia e sem vicio", "preta nova e com duas crias" etc. 
problematizar a diferença contraditória constitutiva das sociedades, posto que promove uma escuta das forças em jogo em uma formação social, forças que não necessariamente antagonizam, mas se enfrentam e traduzem através de sua história (ALTHUSSER, 2008, p. 43). Assim, ao estender o conceito de enunciado à formulaçáo visual, Lagazzi (2015) admite formas de escutar o social que gritam nas composiçóes visuais, permitindo atar uma escuta social a um olhar crítico dos modos de constituição de sentidos.

Nesta "cena prototípica" que se dá em Mãe preta, o olhar metaforiza a "diferença no social", isto é, constitui, no simbólico, uma "alteridade contraditória” (LAGAZZI, 2015, p. 187) própria à formação social, pois estabelece posiçóes ideológicas disjuntivas, que se presentificam no equívoco a forjar um ponto de fuga na leitura da formulação visual. Se, pela via da psicanálise, o ato poético enseja uma tentativa de testemunhar algo do real, é entretanto por meio do equívoco que ele, enquanto ato, se constitui. Sua consideraçáo implica, na perspectiva da Análise de Discurso, o reconhecimento da ideologia como mecanismo que "funciona pelo equívoco e se estrutura sob o modo da contradição"; o equívoco, enquanto fato discursivo, se dá no funcionamento da ideologia e/ou do inconsciente, ele "é a inscrição da língua (capaz de falha) na história” (ORLANDI, 2001, p. 102). O olhar aponta para a instância de um lugar outro, constituído pela falta, desloca o sujeito de um lugar social ao abrir uma brecha no processo de identificação, pensado na relação com a cadeia significante; ele textualiza, na formulação visual, um flagrante da falha no ritual ideológico, a qual permite pensar a insurreição como um efeito de ressonância que toma a dimensáo de um acontecimento histórico, produzindo um outro sentido para a maternidade e para o sujeito mulher. O olhar sustenta, portanto, um ponto de fuga na leitura da cena, desestabiliza interpretaçóes sobre a presumida passividade em que o corpo da mulher negra é construído e, ainda, desregula a pretensa naturalidade de seus atributos de ama cuidadora: ao inaugurar um lugar para que o poético e o político se instalem, o olhar acolhe o acontecimento na estrutura, possibilitando outras escutas e interpretaçóes.

\section{No olhar, o grito de um corpo em silêncio}

Em Babá brincando com criança em Petrópolis (Figura 2), clicada em 1899 por Jorge Henrique Papf, é outra vez o olhar que instala o ponto de captura, punctun, e produz um efeito de ressonância, como se o corpo da babá negra fotografado cravasse em nós seu próprio olhar aterra(dor). 
No vislumbre dessa imagem, podemos dizer, parafraseando Barthes: vejo os olhos que viram o terror da escravidão. $\mathrm{O}$ olhar como experiência sensível convoca, nesta imagem, o não-sentido, no olhar de enfrentamento, confronta(dor) com que a babá negra encara aquele que a olha, seu especta(dor) e, neste olhar, desestabiliza a suposta intencionalidade que persegue o ato do fotógrafo ao clicar a cena, admitindo que o olhar do espectador, no gesto de leitura da imagem, também hesita; despossuídos do lugar de puro espectador, é preciso consentir que "diante de uma imagem, algo nos olha” (BALDINI; CHAVES, 2018, p. 803).

Ao flagrar um acontecimento doméstico ordinário e corriqueiro, enquadrado e capturado para integrar um reles álbum de família, essa "cena prototípica" dá a ver o social e a alteridade a partir de uma relação dicotômica. Nela, o corpo negro da babá e o corpo branco da criança são elementos que estruturam a formulação visual, posto que sintetizam a estigmatização social de determinados corpos. Trata-se de uma cena em que a violência se impóe incomensurável, onde habita um corpo negro carregado de memória e história, constituído por uma construçáo social que o significa como abjeto e animalizado. Corpo que textualiza, na fotografia, o social em contraposição ao corpo branco da criança, a estabelecer, pela via da contradição, uma divisão que se radicaliza na evidência da docilidade e da submissão. Assim, ao interrogar essa evidência de subordinação, procuramos sustentar que há, nesse corpo, algo que re(existe) às injunçôes impostas pelo exercício do poder na formação social brasileira oitocentista. Algo que, como um "sopro de irregularidade", irrompe na cena e se presentifica no corpo, pelo olhar desesbabiliza(dor) a constituir o campo indizível da imagem; o olhar que, ao funcionar como uma metonímia do corpo da babá, fascina seu observador, estabelece com ele uma relação visceral, o transpassa pela forma pungente com que presentifica o não decifrável, o indizível. Na fotografia, o olhar traz a marca sensível de um acontecimento do corpo, em que um grito mudo instala a falha no/do simbólico, a compor os limites da representação fotográfica. No silêncio desse corpo arquejado e aparentemente embrutecido pela aspereza da cena, o olhar estabelece uma abertura ao processo de significação, permitindo outros sentidos para a mulher negra. 


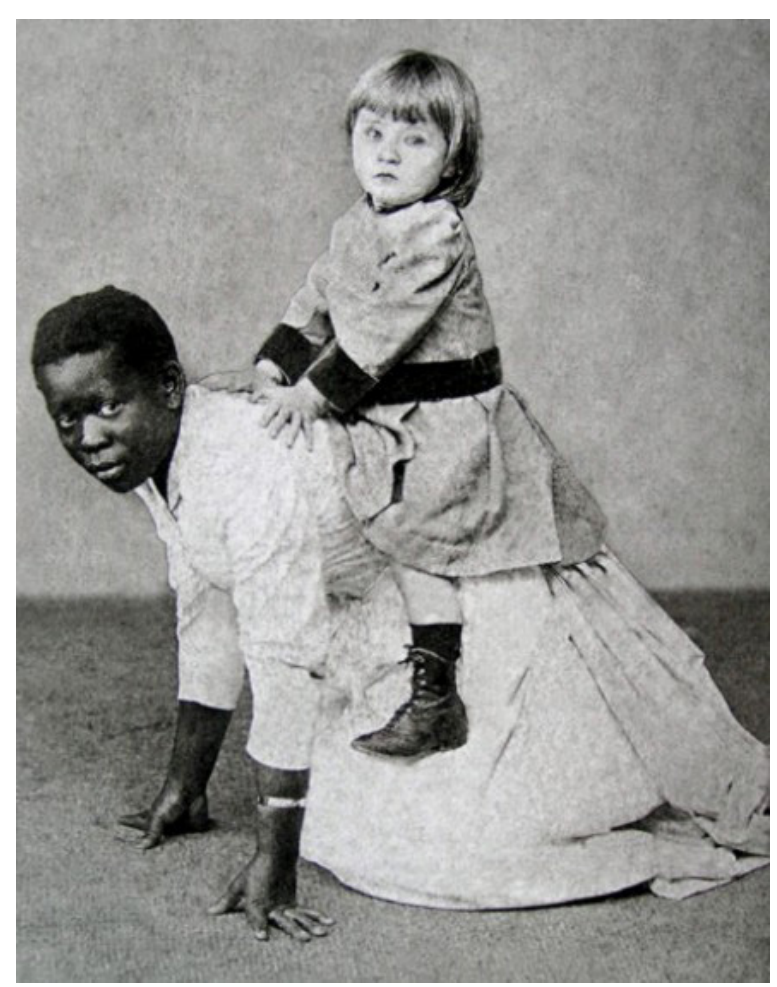

Figura 2: Babá brincando com criança em Petrópolis, clicada em 1899 por Jorge Henrique Papf. Fonte: LÖFGREN; GOUVÊA, 2018

Na trilha do que Pêcheux (2009, p. 278) estabelece em uma célebre nota de rodapé de sua retificação a Les vérités de La Palice, consideramos que a resistência irrompe nesse olhar (de insubordinaçáa?) como "ponto de realização impossível do assujeitamento 'perfeito"', como a aparição fugidia de uma coisa de uma outra ordem, e a partir do qual é possível consentir em um modo de resistência realizado no e pelo corpo. O olhar impóe-se, entáo, "contra a repetiçáo e o nada", estabelece um indício que materializa, no corpo, vestígios de resistência em um processo que se realiza nos tropeços e falhas dos rituais que regem o funcionamento do social. Esse olhar textualiza, ao confrontar seu observador, a falha no processo de assujeitamento; ele atravessa e dilacera a fotografia ao instituir o litígio constitutivo de posiçóes 
sujeito irreconciliáveis, em permanente confronto. É o olhar que permite, ao investir-se na contradição constitutiva desse jogo de linguagem, escapar à mortificação na relação com o cinismo estabelecido na formulação que intitula a cena "Babá brincando com criança em Petrópolis". Ele estabelece, então, um efeito de torção nos sentidos constitutivos do enunciado, abrindo a cena a outras possibilidades de interpretação.

Em seu livro As formas do silêncio no movimento dos sentidos, Eni Orlandi (1995) argumenta, ao distinguir o silêncio fundador das políticas de silêncio, que o não-dizer significa. Ele não consiste, portanto, numa ausência de sentidos, mas naquilo que, tendo sido interditado em determinada formação social, significa de uma outra maneira. Ao pensar o silêncio em relação ao corpo do sujeito, consideramos que um corpo em silêncio é, também, um modo de produzir sentidos que difere do corpo silenciado pelas políticas de silenciamento trabalhadas pela autora. Há uma opacidade própria ao silêncio, materializada neste fragmento discursivo por meio de uma interdição ao dizer, do silenciamento de lugares de enunciaçáo. No gesto de perscrutaçáo desse corpo silenciado, o olhar inscreve um grito como resposta ao impossível, forma de dar borda ao inominável - à barbárie; no olhar, um gesto que marca uma posição que grita diante (e em) do silêncio.

O olhar vítreo que se assemelha a um brilho molhado de lágrimas comparece na próxima cena (Figura 3 ) em que a ama encara seu espectador, a fotografia Babá com menino Eugen Keller, capturada em 1874 por Alberto Henschel. Na versão atualizada para a mostra Mãe Preta, organizada por Isabel Löfgren e Patricia Gouvêa (2018), a fotografia recebe a interferência de um objeto, uma lupa, que realça a qualidade dos olhos da babá. "Esses olhos representam uma vida sem escolhas. São abatidos e desalentados, medrosos e obedientes, entediados e ansiosos, envergonhados, exaustos ou, às vezes, claramente desafiadores", afirma Qiana Mestrich (2018), em um texto sobre as fotografias e imagens de mulheres negras em condiçấo de amas de leite e cuidadoras, redigido para o catálogo da exposição. Em suas análises, Qiana confirma a importância da circulação de imagens de corpos de mulheres negras, especificamente seus ventres e seios, na construção da ideia de uma suposta naturalização de suas capacidades reprodutivas. Em retratos de estúdios como esse, era comum que a ama posasse com os seios à mostra, amamentando uma criança. Para a autora, "as fotografias funcionavam como objetos coloniais que não só transformavam a mãe negra em caricatura como também reforçavam as fantasias brancas (masculinas) sobre essa mulher como sendo uma Jezebel, governada pela libido [...]" 
(MESTRICH, 2018, p. 69 - grifo da autora). Assim, embora vestida com recato, Babá com menino Eugen Keller é exemplar de uma imagem recorrente nos álbuns das famílias no Brasil oitocentista, e que apresenta um funcionamento discursivo paradoxal: "ironicamente, essas fotografias de família tornaram as escravizadas negras tecnicamente visíveis, ainda que

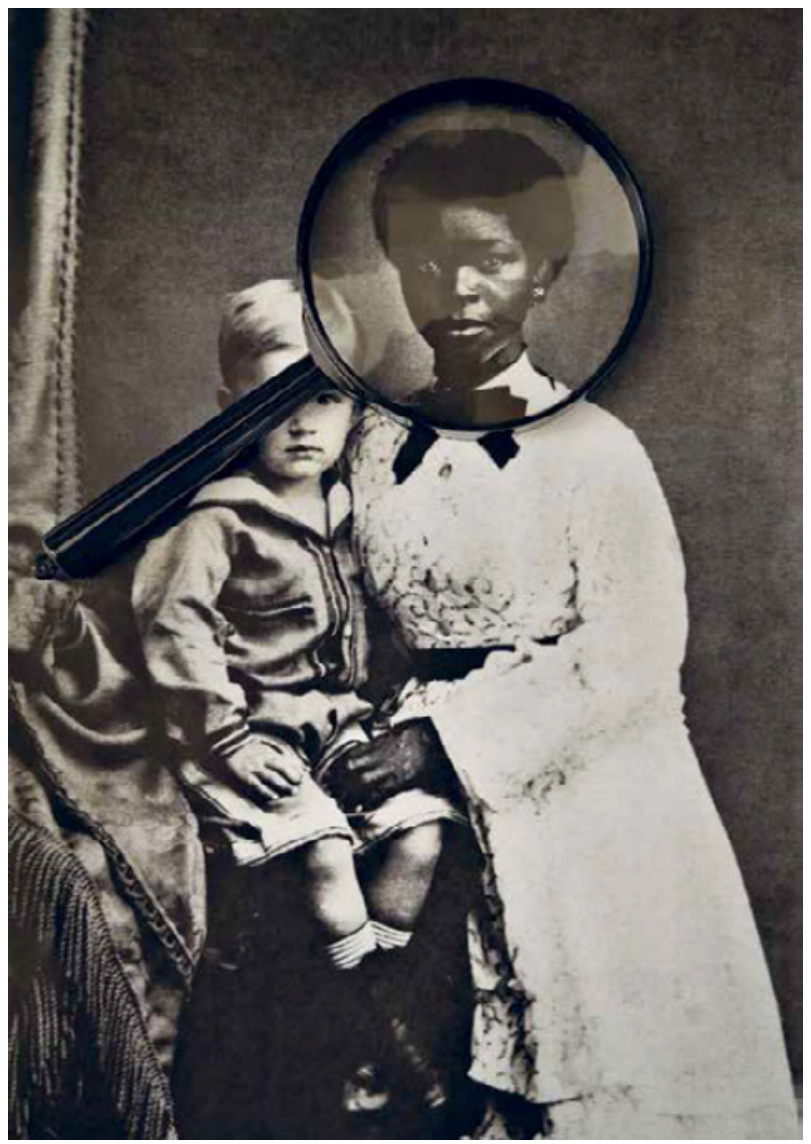

fossem socialmente invisíveis" (MESTRICH, 2018, p. 68 - grifo da autora).

Figura 3: interferência sobre fotografia de Babá com menino Eugen Keller (1874).

Fonte: LÖFGREN; GOUVÊA, 2018

Para Orlandi (1990, p. 17 - grifo nosso), “[...] o que é visto ganha estatuto de existência. Ver, tornar visível, é forma de apropriação”. Embora 
esteja tratando especificamente do discurso do descobrimento do Brasil a partir do enunciado "Terra à vista", a reflexão da autora possibilita admitir que o visível estabelece o conhecimento do objeto, permitindo assim apreendê-lo. Entretanto, conforme testemunhamos a partir desse retrato, a visibilidade não garante reconhecimento de uma vida. Segundo Butler (2015), as normas mediante as quais os sujeitos são constituídos produzem e deslocam os termos por meio dos quais opera o reconhecimento; embora não sejam deterministas, posto que dependem de amplas operaçóes de poder, são normas que facilitam ou dificultam o reconhecimento de uma vida. $\mathrm{O}$ que somos capazes de apreender depende de condiçôes historicamente articuladas, que determinam as "condiçôes de ser reconhecido", as quais moldam um ser vivo em sujeito reconhecível, ainda que não sejam infalíveis ou isentas de efeitos imprevisíveis. Para a autora, "há sujeitos que não são exatamente reconhecíveis como sujeitos e há vidas que dificilmente - ou, melhor dizendo, nunca - são reconhecidas como vidas" (BUTLER, 2015, p. 17). Por sua vez, o enquadramento, ao delimitar a esfera da aparição como uma moldura constituída politicamente, delibera quais vidas são reconhecíveis e merecem ser enlutadas: "não há vida nem morte sem relação com um determinado enquadramento" (BUTLER, 2015, p. 22):

\footnotetext{
Nós só começamos a "existir" em virtude dessa dependência fundamental com respeito ao endereçamento do Outro. Nós existimos não apenas porque somos reconhecidos, mas, mais fortemente porque somos reconhecíveis. Os termos que facilitam o reconhecimento são eles mesmos convencionais, são eles mesmos efeitos e instrumentos de um ritual social que decide, frequentemente pelo recurso à exclusão e à violência, as condições linguísticas de sujeitos viáveis (BUTLER, 2015, p. 25, grifo nosso).
}

Há, portanto, condiçôes para a constituiçâoo de sujeito viáveis, condiçóes determinadas ideologicamente, acrescentaríamos. Retomando o recorte apresentado na Figura 3, ao re-enquadrar a cena fotografada, pela introdução da lupa como elemento que vem a perturbar o funcionamento parafrástico que reitera, na atualidade, a memória colonial, a interferência artística desloca os sentidos estabelecidos para a ama ali retratada, por meio de um gesto reflexivo que instala uma crítica ao campo visual. Trata-se, talvez, de uma forma de "enquadrar o enquadramento" (BUTLER, 2015, p. 23) que questiona a (in)visibilidade social das mulheres negras, denuncia uma ideologia que excede os limites visíveis da moldura e um enquadramento que busca não só conter e transmitir o que é visto, ou seja, organizar a experiência visual, mas também determinar ontologias específicas do sujeito, 
disposições afetivas e éticas que decidem por sujeitos viáveis e inviáveis.

\section{Enquadramentos de maternidade para a mulher encarcerada}

Há atualmente cinquenta e oito, divididas por três salas, uma das quais é enfermaria. À falta de lugares, a promiscuidade é ignóbil nesses compartimentos transformados em cubiculos. A maioria das detentas, mulatas ou negras, fúfias da última classe, são reincidentes, alcoólicas e desordeiras. Olho as duas salas com as portas de par em par abertas e fico aterrado. Há caras vivas de mulatinhas com olhos libidinosos dos macacos, há olhos amortecidos de bode em faces balofas de aguardente, há perfis esqueléticos de antigas belezas de calçada, sorrisos estúpidos navalhando bocas desdentadas, rostos brancos de medo, beiços trêmulos, e no meio dessa caricatura do abismo as cabeças oleosas das negras, os narizes chatos, as carapinhas imundas das negras alcoólicas. Alguns desses entes, lembra-me tê-los visto noutra prisão, no pátio dos delírios, no hospício. É possível? Haverá loucas na detençáo como há agitados e imbecis? O Dr. Afrânio Peixoto, o psiquiatra eminente, disserame uma vez, apontando o pátio do hospício, onde, presas de agitação, as negras corriam clamando horrores aos céus: - Há algumas que têm quatro e cinco entradas aqui. Saem, tornam a beber e voltam fatalmente (RIO, 1908, $\mathrm{s} / \mathrm{p}$ - grifos nossos). 


\section{Artemis adicionou 2 novas fotos.}

$1 \mathrm{~h} \cdot \mathrm{O}$

Não tem flores, nem homenagens, nem parto humanizado, nem aleitamento materno exclusivo para as mulheres no cárcere. Eu já tinha ouvido falar sobre como é difícil exercer a maternidade nessa situação, mas há pouco tempo ouvi relatos e o que acontece com essas mulheres e com os bebês e olha é pior do que poderia supor... Um exemplo disso é que cada dia de trabalho reduz um dia na pena, por isso há mães que "escolhem" não amamentar o bebê para acabar logo a pena.

Flávia Ribeiro, uma ativista em construção e colaboradora da Fanpage Aqui vai um link sobre a situação no Brasil http://oglobo.globo.com/infografi.../especial-mulheres-presas/

Aqui vai um link sobre o dia das Mães de uma mulher no cárcere. http://g1.globo.com/.../detenta-da-luz-em-cima-de-saco-plasti...

Tirei uma imagem daqui (http://monitoramentocedaw.com.br/.../maespresas-filhos-conde...)

A outra foto daqui (http://irenegarciaperulero.com/feminista/)
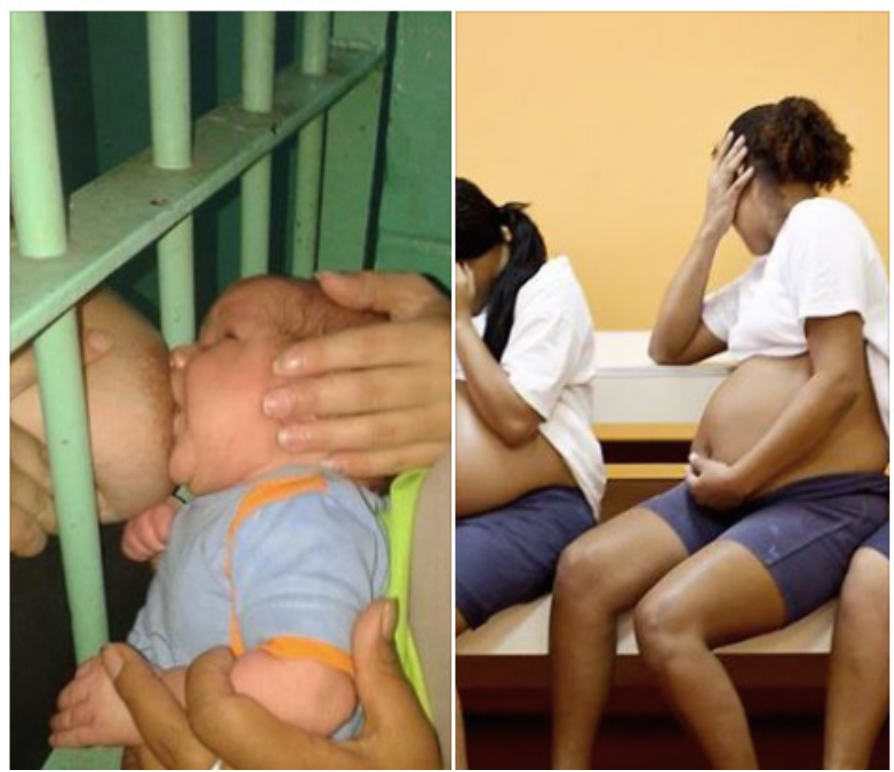

Figura 4: Postagem em "comemoraçấo" ao dia das mães, realizada em 2015. Fonte: Facebook. 
Trazemos, nesse último recorte, uma postagem do dia 12 de maio de 2015, realizada pela Associação náo-governamental Artemis em "homenagem" (termo que usamos com muitas aspas) ao dia das mães. Nela, as fotografias se impóem ao olhar, produzindo efeitos que se textualizam nos comentários presentes na materialidade significante do post. No modo como enquadra a mulher e o bebê, a primeira fotografia oferece uma direção interpretativa na qual a mulher é significada a partir de um funcionamento metonímico: seus sentidos se constituem por meio de um fragmento de seu corpo, o seio que amamenta. A grade que separa os corpos da mãe e de seu filho materializa, nessa formulação visual, a fronteira que separa o dentro e o fora, a delimitar o espaço físico e simbólico do cárcere; ela demarca uma formação discursiva constitutiva de sentidos para a maternidade de mulheres negras a partir de um não-lugar social, uma ausência de lugares frente à sociedade. Ela é a manifestação, na linguagem, de um processo de segregação, realizado através da violência, que inscreve essas mulheres na formaçáo discursiva da delinquência, a qual compóe, tangenciada a outras formaçôes discursivas, uma complexa articulação entre formaçóes ideológicas.

Ancorada na ideia do espaço como enquadramento proposta por Paul Henry, Orlandi (2009) estabelece que os sentidos são determinados pelo modo como o espaço enquadra o acontecimento, determinando seu espaço de significação. Sua elaboração nos permite ponderar que disposições diferentes de espaço constituem diferentes sujeitos e sentidos. Assim, a grade que supostamente "protege" um morador em um condomínio residencial difere profundamente da grade que separa essa mãe presidiária de seu filho recém-nascido, posto que constituem espaços de significação diferentes, dadas suas condiçóes particulares de produção, embora crivados pela dicotomia dentro-fora. "Daí se conclui, portanto, que o espaço significa, tem materialidade e não é indiferente em seus distintos modos de significar, de enquadrar o acontecimento" (ORLANDI, 2009, p. 224, grifo da autora). Em sua noçáo significativa de espaço, Orlandi articula o material (físico e espacial) e o humano, o simbólico e o político, ligando a questão do espaço à questão do sujeito e à da memória.

$\mathrm{Na}$ postagem em análise, a grade demonstra o fato de que o capitalismo se mantém em sua dominância, amparado pelo preconceito, considerado "uma discursividade que circula sem sustentação em condiçóes reais e fortemente mantida por condiçóes imaginárias que silenciam sentidos" (ORLANDI, 2009, p. 223). Há, portanto, um imaginário social que direciona e hierarquiza a direção dos sentidos, imaginário que divide 
os sentidos de maternidade, alocando-os diferencialmente quando esta diz respeito à mulher branca ou à mulher negra. Não é demais lembrar que, não por acaso, a grande maioria das mulheres que vive dentro do sistema prisional brasileiro é negra. Muitas dáo à luz dentro dos próprios presídios, na maior parte das vezes em condiçóes extremas de abandono e violência. A maternidade da mulher negra segue, então, uma rota traçada sócio-historicamente, em que o passado ressoa constantemente no presente, negando a essas mulheres a possibilidade de exercer minimamente a maternidade com dignidade. Isso acontece, segundo Butler (2015, p. 70), porque "as vidas são divididas entre aquelas que merecem ser defendidas e enlutadas quando são perdidas, e aquelas que não são propriamente vidas nem propriamente valiosas, reconhecíveis ou possíveis de serem enlutadas".

À mulher encarcerada resta um lugar de interdição, textualizado, na formulação que acompanha as fotografias, pela negação: "Não tem flores, nem homenagens, nem parto humanizado, nem aleitamento materno exclusivo para mulheres no cárcere". Palavras que denunciam ao produzir certa visibilidade para a mulher encarcerada, que delatam o fato de que, numa sociedade democrática como a nossa, que sustenta o mito do sujeitode-si e para si, o "outro" será sempre o estranho cuja existência é insuportável. Nos comentários, é possível apreender as ressonâncias desses processos de produção de sentidos: "É de cortar o coração esta imagem do bebê" (grifo nosso), diz uma comentadora. Diante dessa imagem contemporânea, operadora de memória social, a formulaçáo que figura nesse comentário faz ver uma ausência, textualizada em seu corpo textual. Aquilo que permanece excluído do enquadramento da fotografia, para além de suas margens, aquele fora do campo de visão que o olhar captura, é justamente a mulhermãe que amamenta, presente pela falta - ou ausente em sua presença. Como nos ensina Orlandi (2009, p. 223), "o preconceito nega a própria existência do ser".

A falta instaurada pela interdição de determinados sentidos de maternidade às mães encarceradas se liga necessariamente à falha do Estado, por meio da articulação entre Aparelho Ideológico e Aparelho Repressor. Segundo Orlandi (2012, p. 230), "a falha do Estado é estruturante do sistema capitalista", ou seja, na sociedade de mercado, o Estado falha em sua função de articulador simbólico e político: "Não é uma falta de interesse, um descaso, nem, ao meu ver, ele é substituído pelo Mercado. Essa falha é uma falha necessária para o funcionamento do sistema” (ORLANDI, 2012, p. 229). Esse sujeito mulher-mãe-negra se individua, assim, pela falta, na falha do Estado, o que contribui para que se estabeleça seu processo de segregação. 
Para compreender como isso acontece, reportamos às elaboraçóes de Orlandi, que ao pensar o sujeito e os processos de individuação, parte da interpelação do indivíduo em sujeito pela ideologia, no simbólico, processo que constitui a forma-sujeito-histórica: em nossa sociedade capitalista, a forma-sujeito é sustentada no jurídico, pela assunção de direitos e deveres, e da evidência de sua livre circulação social. "As formas de individualização do sujeito pelo Estado, estabelecidas pelas instituiçóes e discursividades, resultam, assim, em um indivíduo ao mesmo tempo responsável e dono de sua verdade, com direitos e deveres e direito de ir e vir" (ORLANDI, 2012, p. 228). É esse indivíduo, assim individua(liza)do pelo Estado, que se identifica com os sentidos de determinada formação discursiva; a individuação funciona, entâo, como pré-requisito aos processos de identificação do sujeito.

Para Orlandi (2012, p. 213), a ideologia e seu funcionamento sustentam no capitalismo formas de onipotência da vontade e da consciência, perceptíveis na posição "se eu quiser, eu posso tudo". Produtora do sujeito como origem e dono de si, essa posição estabelece a ilusão da transparência do sujeito para si mesmo; ela constitui, no mesmo gesto de engendramento da evidência de si, a transparência do outro ao des-historicizar suas condições reais de existência. Isso mostra que há um mecanismo de esquecimento da complexidade da constituição do sujeito. Ainda, essa posição moralizante admite culpabilidade às mulheres encarceradas por sua própria condição de existência. Assim, ao deslocar a questão do sujeito pragmático e sua culpa moralizante e considerar o funcionamento social a produzir efeitos-sujeito, ponderamos modos de individuação produzidos pelo Estado e que instituem procedimentos pelos quais essas mulheres tornam-se presidiárias, pela via da falha: em vez de individualizá-las, o Estado funcionando pela falha as desindividualiza, e é a partir desse processo que esses sujeitos inscrevem suas posiçôes em formaçóes discursivas, estabelecem, assim, os sentidos que os identificam em suas posiçóes sujeito na sociedade. Desprovida de rosto e simbolizada pelo seio, por um corpo recortado e despedaçado, essa mãe sofre um processo radical de des-subjetivação. $\mathrm{O}$ rosto em falta se liga à falha no funcionamento do jurídico, já que o rosto é a expressão do jurídico, segundo Levinas (apud FELMAN, 2014, p. 82), "a visão do rosto é um correlativo do surgimento da ética e da justiça, e que rigorosamente define violência como a supressão do rosto".

Orlandi defende que, na atualidade, as relações sociais já não podem ser pensadas a partir dos termos da exclusão versus inclusão. Como coloca Schaller (2001 apud ORLANDI, 2009, p. 227), hoje os sujeitos se produzem em uma "relação horizontal de segregaçáo: ou se está dentro ou fora. Uma 
vez segregado, é impossível ao sujeito entrar nas relaçóes sociais”. A análise de Orlandi tem um sentido mais forte, como ela mesma coloca: "segregado é aquele que não tem direito de existir. É o sujeito à extinção" (ORLANDI, 2009, p. 227). O que a autora tem tratado como delinquência ultrapassa, assim, a exclusão, atribuindo um sentido particular à marginalidade. Segundo ela, a "delinquência é a perda dos laços sociais e por eles o vínculo com a história. O Estado, nessas condiçôes, falha em sua capacidade de articulador simbólico e os sujeitos vivem no sem-sentido praticando a delinquência" (ORLANDI, 2009, p. 224). Em uma ordem discursiva em que os processos de significação encontram-se sedimentados, tendo sido des-individuada, essa mãe sucumbe ao sem-sentido, posto que não é possível subjetivar-se de outro modo, habitar um outro espaço e simbolizar-se no social. Entretanto, em face desse aparente assujeitamento perfeito pela ideologia, que desumaniza o corpo negro feminino e funciona a partir de processos discursivos metafóricos e metonímicos que jogam com sua fragmentação, é necessário questionar: será que esses corpos são corpos que resistem e, sobretudo, simbolizam essa resistência? Retomando o último recorte, é possível dizer que talvez haja, na imagem, algo da ordem do equívoco a possibilitar sentidos outros para essa mãe: o olhar do bebê em sua direção. É, mais uma vez, o olhar para um "fora da cena" que instala o ponto possível para a fuga de sentidos, possibilitando, talvez, uma abertura no processo de significação. Isto quer dizer que a maternidade pode vir a constituir um outro espaço para o sujeito significarse; ela pode tornar possível um movimento nos processos de individuação, fazendo com que essas mulheres passem do náo-sentido ao sentido possível.

No que diz respeito aos discursos jurídicos e midiáticos constitutivos de modos de formulação e circulação dessa postagem, além do caráter próprio ao discurso da mídia e seu eco vazio, consideramos que o campo do direito simula um funcionamento lógico dedutivo no qual a lei universal é supostamente aplicada a todos. Assim, é possível sustentar que, em uma sociedade em que há contradição de classe, a universalidade produzida por tais discursos é um efeito imaginário necessário à reprodução das relaçóes de produção. Nesta medida, a visibilidade da condição de existência da mulher-mãe negra em situação de cárcere, possibilitada por alguns discursos de militância, instala um acontecimento, através da desestabilização nos processos de significação, e faz furo no efeito de universalidade próprio ao funcionamento jurídico, ao delatar o atravessamento do discurso jurídico e da violência institucional que o Estado perpetra. Desse modo, esses discursos de militância, embora constituídos pelo funcionamento das mídias, desvelam, em seus efeitos de denúncia, as fronteiras entre as 
formaçôes discursivas, desfazendo processos que dissimulam as contradiçôes constitutivas da nossa formação social, e que camuflam o silenciamento e o ódio ao outro. É precisamente nesse lugar de apreensáo de um outro que, por conta de sua diferença, náo cabe, que é possível reconhecer e denunciar as relaçóes de força que atravessam os discursos, traçando neles fronteiras invisíveis.

\section{Momento de concluir}

No exame de processos históricos que determinam as práticas discursivas constitutivas de sentidos para a maternidade em nossa formação social, e questionando o caráter profundamente dividido de tais discursos (COURTINE, 2009), discorremos, neste artigo, sobre imagens que integram um quadro de violência de gênero, sexualidade, raça e classe no Brasil. Imagens que trazem, cravadas em suas formas materiais, isto é, em suas formulaçôes visuais, um ponto de convergência: o olhar, a instalar lugares para a fuga de sentidos (ORLANDI, 2012b), a possibilitar deslocamentos nos processos de significação. Imagens que são em si acontecimentos, pois situam o lugar de encontro entre uma atualidade e uma memória, e que colocam em cena a questáo do enquadramento de sujeitos e corpos ou, ainda, de como um enquadramento seletivo e diferenciado da violência regula disposiçóes afetivas e éticas (BUTLER, 2015). Com Baldini e Chaves (2018, p. 816), é preciso insistir no que essas imagens trazem da "ordem do incômodo, da diferença, da denúncia e de uma invisibilidade cotidiana”, cenas que nos olham nos olhos e nos lembram "que nem todo mundo marcha pela mesma causa”. Na malha discursiva que o acontecimento dessas imagens, dispostas em uma série, produz, grita o silêncio do corpo feminino negro, inscrito em presenças e ausências. Corpos que, face à confiscação de lugares de fala, resistem às políticas de silenciamento, à interdição, reverberando um grito contido durante séculos; imagens que fazem furo na evidência dos sentidos constitutivos da maternidade em nossa sociedade, interseccionam posiçóes ao escancarar o avesso de uma formação discursiva.

Ao permitir a abordagem de diferentes materialidades significantes, as análises delineadas recolocam o fato incontornável da interpretação na construção de um dispositivo de leitura que possa "entender a presença de não-ditos no interior do que é dito" (PÊCHEUX, 2002, p. 44). Ainda, ao colocar a questão do enquadramento e da radicalidade da experiência do olhar, abre-se uma via ética para pensar a constituição do sentido e do sujeito, 
na relação com o discurso, a historicidade e o desejo. Às margens da história, a maternidade da mulher negra significa, nas formulaçóes analisadas a partir de molduras e enquadramentos, tecidos por/em posiçóes sujeito masculinas e brancas, constituindo sentidos que as desumanizam, que constroem seus corpos como objetos/abjetos. Como nos ensinou Pêcheux, as barreiras invisíveis que constituem a formação social não separam dois mundos, elas atravessam a sociedade como linhas moventes, sensíveis às relações de força, resistentes e elásticas. De um lado e de outro dessa fronteira, os nomes, as expressóes e enunciados de uma mesma língua não produzem o mesmo sentido. Sendo assim, fechamos nossa reflexão com uma pergunta: Quais práticas e sentidos da maternidade são hoje possíveis para as mulheres negras?

\section{Referências}

ALTHUSSER, Louis. Sobre a reproduçáo. Petrópolis: Vozes, 2008.

BALDINI, L. J. S.; CHAVES, T. V. Do visível ao nomeado: enquadramentos do humano. Trabalhos de Linguística Aplicada. Campinas, n 57.2, 799-820, mai./ago. 2018.

BALDINI, L. J. S.; ZOPPI-FONTANA, M. G. A Análise do Discurso no Brasil. Décalages: Vol.1, Iss.4, Art.22, 2014.

BARTHES, R. A câmara clara. Rio de Janeiro: Nova Fronteira, 2015.

BUTLER, J. Quadros de guerra: quando a vida é passível de luto? Trad. Sérgio Lamarão e Arnaldo Marques da Cunha. Rio de Janeiro: Civilização Brasileira, 2015.

COURTINE, J.J. Análise do discurso político: o discurso comunista endereçado aos cristãos. São Carlos: EDUFSCAR, 2009.

FELMAN, S.. O inconsciente jurídico: julgamentos e traumas no século XX. Trad. Ariani Bueno Sudatti. São Paulo: EDIPRO, 2014.

FREYRE, G. Casa-grande e senzala. 19. ed. Rio de Janeiro: José Olympio Editora, 1978.

GADET, F; PECCHEUX, M. A língua inatingível. Campinas: Pontes, 2010.

HENRY, P. Os fundamentos teóricos da "análise automática do discurso" de Michel Pêcheux. In: GADET, F; HAK, T (Org.) Por uma análise automática do discurso. Campinas: Editora da Unicamp. 4. ed., 2010. 
LAGAZZI, S. Paráfrase da imagem e cenas prototípicas: em torno da memória do equívoco. In: FLORES, ; NECKEL, Na; GALLO, S. (Org.). Análise de discurso em rede: cultura e mídia. Campinas: Pontes Editores, 2015. p. 177-189.

LÖfGREN, I. \& GOUVÊA, P. (Org.) Máe Preta. São Paulo: Frida Projetos Culturais, 2018

MÃE Preta. In: ENCICLOPÉDIA Itaú Cultural de Arte e Cultura Brasileiras. São Paulo: Itaú Cultural, 2019. Disponível em: <http://enciclopedia.itaucultural.org.br/obra3242/mae-preta>. Acesso em: 26 jun. 2019. Verbete da Enciclopédia.

MAGALHÂES, E. K. C; GIACOMINI, S. M. A escrava ama-de-leite: anjo ou demônio? In: COSTA; BARROSO. (Org.). Mulher, mulheres. São Paulo: Cortez/ Fundação Carlos Chagas, 1983.

MESTRICH, Q. Fotografia e maternidade negra: vislumbrando uma autoridade para a maternidade negra. In: LÖFGREN, I. \& GOUVÊA, P. (Org.) Mãe Preta. São Paulo: Frida Projetos Culturais, 2018.

ORLANDI, E. P. Terra à vista. Discurso do confronto: velho e novo mundo. Campinas: Editora da Unicamp, 1990.

. As formas do silêncio: no movimento dos sentidos. 3. ed. Campinas: Ed. Unicamp, 1995.

. Discurso e texto: formulação e circulação dos sentidos. Campinas: Pontes, 2001.

Interpretaçáo: autoria, leitura e efeitos do trabalho simbólico. 5. ed. Campinas (Sáo Paulo): Pontes, 2007.

. Espaço da violência: o sentido da delinquência. In: Caderno de Estudos Linguísticos, Campinas (SP), v. 2, n. 51, p. 219-234, dezembro 2009.

. Discurso em análise: sujeitos, sentido, ideologia. Campinas: Pontes Editores, 2012.

. Sentidos em fuga: efeitos da polissemia e do sujeito. In: CARROZZA, Guilherme; SANTOS, Miriam; SILVA, Telma Domingues (Org.). Sujeito, Sociedade, Sentidos. Campinas: Editora RG, 2012b.

PÊCHEUX, M.. O discurso: estrutura ou acontecimento. 3. ed. Campinas (São Paulo): Pontes, 2002.

. "Papel da memória". In: ACHARD, P. et al. (Org.). Papel da 
memória. Campinas: Pontes, 2007.

. Semântica e discurso: uma crítica à afirmação do óbvio. 4. ed. Campinas (São Paulo): Pontes, 2009.

"Abertura do colóquio". In: CONEIN, B.; COURTINE, J.-J.; GADET, F.; MARANDIN, J.-M.; PECCHEUX, M. (Org.) Materialidades discursivas. Campinas: Editora da UNICAMP, 2016.

RIO, João do. A alma encantadora das ruas. Rio de Janeiro: Fundação Biblioteca Nacional, 1908. 